\title{
ENVIRONMENTAL FILTERS DETERMINE THE DISTRIBUTION OF TREE SPECIES IN A THREATENED BIODIVERSITY HOTSPOT IN WESTERN MEXICO
}

\section{LOS FILTROS AMBIENTALES DETERMINAN LA DISTRIBUCIÓN DE ESPECIES DE ÁRBOLES EN UNA REGIÓN CRÍTICA DE BIODIVERSIDAD AMENAZADA EN EL OCCIDENTE DE MÉXICO}

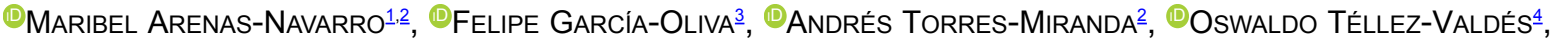 \\ CKEN OYAMA ${ }^{2 *}$
}

\begin{abstract}
1Posgrado en Ciencias Biológicas, Universidad Nacional Autónoma de México, México.
${ }^{2}$ Escuela Nacional de Estudios Superiores, Unidad Morelia, Universidad Nacional Autónoma de México, México.

${ }^{3}$ Instituto de Investigaciones en Ecosistemas y Sustentabilidad, Universidad Nacional Autónoma de México. Morelia, Michoacán, México.

${ }^{4}$ Laboratorio de Recursos Naturales, UBIPRO Facultad de Estudios Superiores Iztacala, Universidad Nacional Autónoma de México. México.
\end{abstract}

*Corresponding author: kenoyama@unam.mx

\begin{abstract}
Background: Analyzing interactions between vegetation and environmental factors at regional scales provide information for the understanding of species assemblages.

Hypotheses: Environmental restrictions at higher elevations produce a decreasing species richness pattern along an elevational gradient and the climatic variables related to temperature and precipitation are the main filters of species distribution.

Objectives: (1) To identify the different assemblages of tree species occurring in a biodiversity hotspot; (2) to analyze the pattern of tree species richness along an elevational gradient; and (3) to analyze the environmental filters that determine the species distribution.

Study site: Serranías Meridionales of Jalisco in western Mexico.

Period of study: 2016-2018.

Methods: Thirty-three rectangular 0.1 ha plots were established for vegetation and environmental characterization. Cluster and canonical correspondence analyses were conducted to analyze tree species composition. We defined three groups of variables (climatic, relief and soil) to evaluate the influence of environmental filters. We used generalized linear models to assess the contribution of each group to the spatial variation in species richness.

Results: A total of 63 tree species were recorded. The cluster analysis defined eight groups within three forest types. The species richness showed a hump-shaped pattern along the elevational gradient and the climatic and soil variables explained a considerable amount of variation in the species richness.

Conclusions: The tree species richness in the Serranías Meridionales of Jalisco is dominated by a striking number of Pinus and Quercus species. This biodiversity hotspot is an important site for the understanding of tree ecological diversification in Mexico.
\end{abstract}

Keywords: Biodiversity hotspot, environmental variables, Pinus, Quercus, species richness.

\section{Resumen}

Antecedentes: El análisis de las interacciones entre la vegetación y el ambiente a escalas regionales permite entender el ensamblaje de especies.

Hipótesis: Restricciones ambientales en sitios elevados generan un patrón decreciente de riqueza de especies en gradientes altitudinales y la temperatura y la precipitación son los principales filtros de la distribución de especies.

Objetivos: (1) Identificar los diferentes ensamblajes de especies de árboles en una región crítica de biodiversidad; (2) analizar la riqueza de especies arbóreas en un gradiente altitudinal; (3) analizar los filtros ambientales que determinan la distribución de especies.

Sitio de estudio: Serranías Meridionales of Jalisco, México.

Período de estudio: 2016-2018.

Métodos: Se establecieron 33 parcelas de 0.1 ha para la caracterización de la vegetación y las variables ambientales. Se realizaron análisis de clasificación y canónicos de correspondencia. Utilizamos tres grupos de variables (climáticas, relieve y suelo) y modelos lineales generalizados para estimar las contribuciones de estas variables a la variación espacial en la riqueza de especies.

Resultados: Se registraron 63 especies de árboles. El análisis de agrupación definió ocho grupos dentro de tres tipos de bosques. La riqueza de especies presenta un patrón de joroba en el gradiente altitudinal y las variables climáticas y de suelo explicaron la variación de la riqueza de especies.

Conclusiones: La riqueza de árboles en las Serranías Meridionales of Jalisco es dominado por un número notable de especies de Pinus y Quercus. Este hotspot de biodiversidad es un sitio importante para el entendimiento de la diversificación de árboles en México.

Palabras clave: Hotspot de biodiversidad, Pinus, Quercus, riqueza de especies, variables ambientales. 
The assembly of plant communities is influenced by several processes, such as historical diversification, environmental filtering, long-term dispersal and ecological interactions, among others (Götzenberger et al. 2011, Zobel 2016, Cavender-Bares et al. 2018). Environmental factors impose filters on species survival, so that only those species that possess the proper attributes to face them can become part of the community (Webb et al. 2002, Götzenberger et al. 2011, de Bello et al. 2012). Environmental filters act at different spatial scales; at the local scale, plant species respond to soil $\mathrm{pH}$, moisture and nutrients (Grime 1979, Pausas \& Austin 2001), while at the regional scale climatic variables are more relevant (Currie 1991, Götzenberger et al. 2011, de Bello et al. 2012).

Plant species richness increases with ecosystem productivity, which in turn is related to high temperature, water availability and resources such as soil nutrients (Currie 1991, Pausas \& Austin 2001, Tuomisto et al. 2014). At the large scale, the water-related variables usually represent the strongest richness predictors in the tropical and subtropical regions for plants (Hawkins et al. 2003, Zhang et al. 2015). At the regional scale, landscape features like mountains play a central role in the regulation of abiotic conditions such as temperature, precipitation, humidity and soil conditions that usually change along an elevational gradient (Beniston et al. 1997, Fiedler \& Beck, 2008). Plant species along elevational gradients in mountainous regions can be affected by temperature, precipitation, topography (i.e., slope steepness and aspect) or soil traits (i.e., soil water retention and fertility), all of which determines the amplitude of their spatial distribution (McCain \& Grytnes 2010, Scherrer \& Körner 2011, Jiménez-Alfaro et al. 2014), although the predominant factors underlying this variability appear to be specific to each taxonomic group (Vázquez-García \& Givnish 1998, Tuomisto et al. 2014).

The understanding of the mechanisms responsible for community diversity along elevational gradients remains controversial (Nogués-Bravo et al. 2008, McCain \& Grytnes 2010). The complex interaction between geographic and environmental variables at varying spatial scales in different mountain systems produces different patterns of plant species richness (Pausas \& Austin 2001, Salas-Morales et al. 2015, Zhang et al. 2015). McCain \& Grytnes (2010) described four main patterns of elevational species richness: decreasing, low plateau, low plateau with a mid-elevational peak and mid-elevational peaks. The decreasing and the mid-elevational or "hump-shaped" patterns are the most frequently reported for plants (Colwell et al. 2004, Kessler et al. 2011, de Bello et al. 2012).

In Mexico, the Mexican Transition Zone is the area where the Nearctic and Neotropical regions overlap (Morrone 2014) and is considered an important biodiversity hotspot for temperate taxa (Challenger \& Caballero 1998, Myers et al. 2000). Temperate forests in Mexico are dominated by plant species with Nearctic affinities that underwent an extraordinary diversification in mountain chains that served as corridors during cool periods (Nixon 1993, Styles 1993, Hipp et al. 2018). Mexican temperate forests are distributed mainly in mountain chains, where the climatic conditions range from subhumid to humid, with freezing temperatures in winter at high elevations (Challenger \& Caballero 1998).

The floristic province of Sierras Meridionales of Jalisco (Torres-Miranda et al. 2011) is an important biodiversity hotspot due to its high species richness and endemism (González-Villarreal 1986, 2018, Gernandt \& Pérez de la Rosa 2014). In the Sierras Meridionales of Jalisco the climate along the elevational gradient shows a linear decrease of temperature and a more pronounced precipitation seasonality in lowlands (SMN 2017).

Vázquez-García \& Givnish (1998) identified a decreasing pattern of species richness along the elevational gradient in the Manantlán Biosphere Reserve, where oaks were the dominant species at high elevations. Elsewhere, studies have reported that elevation is an important factor for determining oak species assemblages (Morales-Saldaña 2017, Torres-Miranda et al. 2011, 2013). Therefore, studies on the interaction between plants and environmental factors are relevant for the understanding of how plants respond to changes in climate that in turn determine the assemblages of plant communities.

The aim of this study was to analyze the effects of environmental filters on the occurrence of different species assemblages in a biodiversity hotspot in western Mexico. The objectives of this study were: (1) to identify the different assemblages of tree species that occur in the Sierras Meridionales of Jalisco, (2) to examine the pattern of tree species richness along an elevation gradient, and (3) to analyze the environmental filters that determine the distribution of the dominant genera. In this study, we tested the following hypotheses: (1) the resource and temperature restrictions at upper elevations cause a decreasing species richness pattern; (2) the climatic variables related to temperature and precipitation are the main filters of the tree species distributions.

\section{Materials and methods}

Study site. The study site was located in the Serranías Meridionales of Jalisco floristic province (Torres-Miranda et al. 2011), which comprises the "El Tuito-El Cuale-Talpa de Allende" Sierras (20 20.885'- $20^{\circ} 9.008^{\prime} \mathrm{N}$, and $105^{\circ}$ $\left.19.162^{\prime}-104^{\circ} 40.106^{\prime} \mathrm{W}\right)$. These mountain complexes are located within Cabo Corrientes and Talpa de Allende counties in Jalisco state, Mexico (Figure 1), at the boundary 


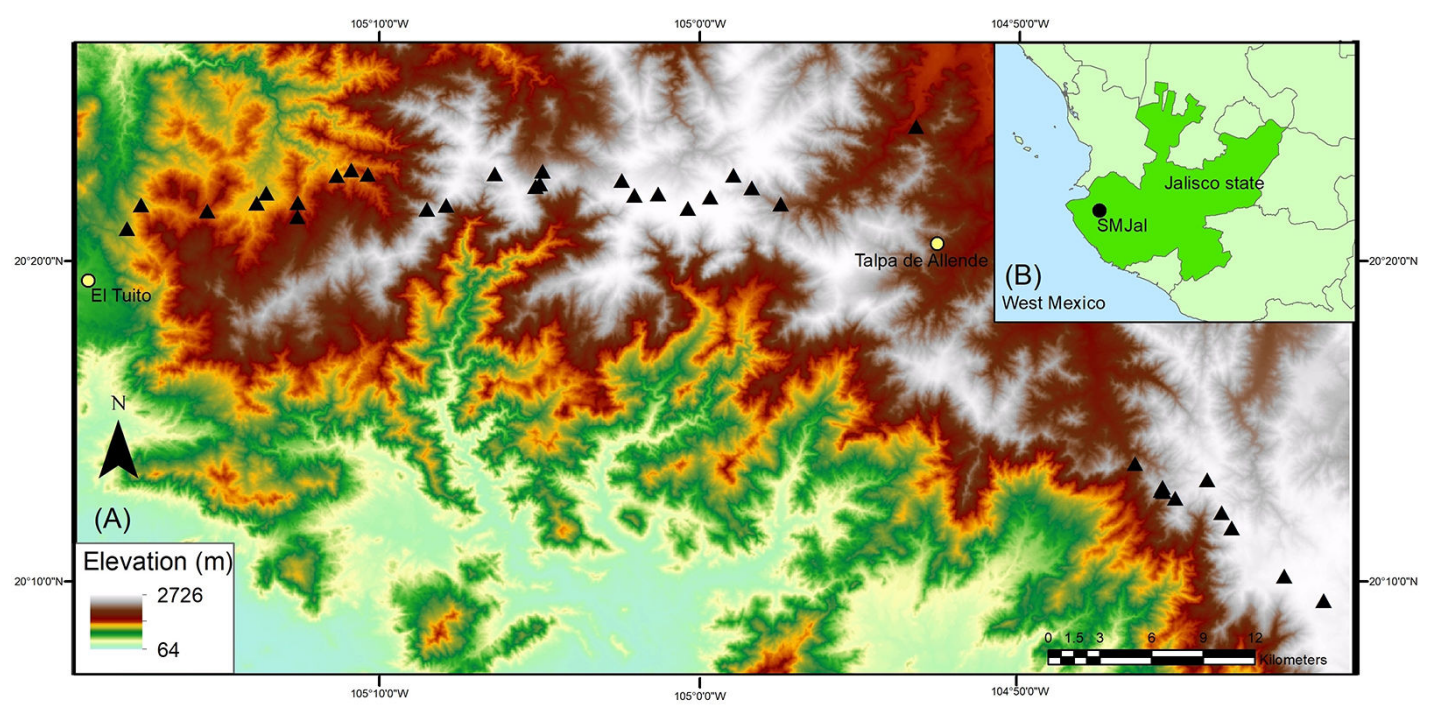

Figure 1. Study region. (A) Location of the Serranías Meridionales of Jalisco (Jalisco Southern Sierras) in Mexico, (B) Jalisco state and the Serranías Meridionales of Jalisco (SMJal). The black triangles represent the location of the vegetation sampling plots relative to the elevational gradient.

of the Sierra Madre del Sur and the Trans-Mexican Volcanic Belt biogeographic provinces, and they encompass an elevational gradient from 650 to $2,738 \mathrm{~m}$. The dominant soil groups are Cambisol and Regosol (INEGI 2007). The mean annual temperature ranges from 28.5 to $30.6{ }^{\circ} \mathrm{C}$ and the annual precipitation ranges from 1,500 to $1,800 \mathrm{~mm}$, with $80 \%$ of the rainfall concentrated between June and October (SMN 2017). In this region, the most common forest types are deciduous forest, oak forest, pine-oak forest, cloud forest, fir forest and its different transition zones (CuevasGuzmán et al. 2010, Velázquez-Ruiz et al. 2012). This floristic region is considered one of the most important centers of floristic endemism (Hernández-López 1995, González-Gallegos \& Castro-Castro 2012, VargasRodríguez et al. 2010, de la Riva et al. 2019), and according to the Mexican Biodiversity Commission (CONABIO) belongs to a priority hydrological basin and a priority land region due to its high biological value in Mexico (ArriagaCabrera et al. 2000, Arriaga-Cabrera et al. 2002).

Data collection. A total of 33 rectangular 0.1 ha plots $(50 \times 20 \mathrm{~m})$ were established to conduct vegetation sampling and soil characterization. In each plot, all trees with $\mathrm{DBH}>15 \mathrm{~cm}$ were recorded. Specialists provided taxonomic identifications and vouchers were deposited at the National (MEXU) and Facultad de Ciencias (FCME) herbaria, both at Universidad Nacional Autónoma de México (UNAM).

Climatic and relief variables. The climatic variables for the study region were obtained using the climatic surfaces reported by Cuervo-Robayo et al. (2014) and interpolated using the algorithm of thin plate smoothing splines implemented in ANUSPLIN 4.36 (Hutchinson 2006), using a digital elevation model with $60 \mathrm{~m}^{2}$ resolution. Nineteen climatic variables were extracted for each plot and then potential evapotranspiration and the aridity index proposed by the United Nations Environment Programme (UNEP) were calculated (Middleton \& Thomas 1997) (see Appendix 1 for the calculations). Additionally, three relief variables (slope steepness, aspect and elevation) were estimated from the digital elevation model, which was processed with the Spatial Analyst tool (ESRI 2013) of Geographical Information System ArcGIS ver. 10.2.

Edaphic characterization by plot. Composite soil samples were collected in the rainy season (August and November 2016) in each plot. The samples were stored in hermetically sealed plastic bags and placed in darkness at $4{ }^{\circ} \mathrm{C}$ until laboratory analysis. A subsample of all the soil samples by plot was oven-dried at $70{ }^{\circ} \mathrm{C}$ to constant weight, for gravimetric moisture determination and water content adjustment to express nutrient concentration on the basis of dry soil mass. For fresh soil samples, $\mathrm{pH}$ was measured in deionized water (soil/solution ratio, $1: 2 \mathrm{w} / \mathrm{v}$ and litter/ solution ratio $1: 5 \mathrm{w} / \mathrm{v}$ ) with a $\mathrm{pH}$ meter equipped with a glass electrode (Corning). To obtain the total nutrients for the soil samples, total carbon (TC) was determined with a total carbon analyzer UIC model CM5012 (Chicago, USA), by combustion and coulometric detection (Huffman 1977). Total nitrogen (TN) and total phosphorus (TP) were analyzed by colorimetry and were determined following acid digestion in a mixture of concentrated $\mathrm{H}_{2} \mathrm{SO}_{4}$ and $\mathrm{K}_{2} \mathrm{SO}_{4}$ plus $\mathrm{CuSO}_{4}$, the latter as a catalyst; $\mathrm{N}$ was 
determined by a micro-Kjeldahl method (Bremmer 1996) and $\mathrm{P}$ by the molybdate colorimetric method following ascorbic acid reduction (Murphy \& Riley 1962). Finally, to assess available nutrients the available inorganic $\mathrm{N}\left(\mathrm{NH}_{4^{+}}\right.$ and $\mathrm{NO}_{3}^{-}$) was extracted from $10 \mathrm{~g}$ fresh soil subsamples with $2 \mathrm{M} \mathrm{KCl}$, followed by filtration through a Whatman No. 1 paper filter and then determined colorimetrically by the phenol-hypochlorite method (Robertson et al. 1999). The soil sample weight was corrected by moisture content.

Environmental filters. To analyze the influence of environment in the species composition, we defined three groups of environmental variables. The first group included climatic variables, the second group contained relief variables and the third group comprised soil traits. To minimize redundancy among environmental variables, a principal component analysis (PCA) was conducted to recognize the variables with the highest factor loading for each group of variables. Thereafter, Pearson's correlation coefficients were calculated for each group of variables and one variable of highly correlated pairs of variables was eliminated to avoid collinearity in subsequent analysis.

Following this criterion, we selected 15 variables divided into three groups. Group one (G1) six climatic variables were selected: maximum temperature of warmest month (mtwm), minimum temperature of coldest month ( $\mathrm{mtcm}$ ), temperature annual range (tar), precipitation of wettest quarter of the year (pwq), precipitation of coldest quarter (pcq) and UNEP aridity index. Group two (G2) corresponds to the relief variables and comprised elevation, slope steepness and aspect. Group three (G3) was composed by the following soil traits: $\mathrm{TC}, \mathrm{TN}, \mathrm{TP}, \mathrm{NO}_{3}{ }^{-}$, soil $\mathrm{pH}$, and soil moisture $(\mathrm{Sm})$. The variable $\mathrm{TP}$ was transformed with $\log _{10}(x+1)$ due to close to zero values.

Statistical analyses. Cluster analysis.- The importance value index (IVI) for each species was estimated in each plot (Curtis \& Mcintosh 1951). This index is estimated based on the sum of the relative density $(R D i)$ with respect to the total density of trees, relative dominance (RDOi) (based on basal area) relative to total tree dominance, and relative frequency $(R F i)$ relative to total frequency of trees. IVI was calculated as: $\mathrm{IVI}=(R D i+R F i+R D O i) / 3$. The cluster analysis based on the IVIs of all the species was used to establish the species assemblages; with the Bray-Curtis index the interspecific dissimilarity was calculated with an average linkage (unweighted pair-groups method using arithmetic averages; UPGMA) as clustering algorithm (Shen et al. 2015). This was done in the PATN program ver. 3.01 (Belbin 1995, 2003).

A canonical correspondence analysis (CCA) was conducted to relate community composition with the environmental variables (de Bello et al. 2012, Shen et al.
2015). We performed 999 permutations to evaluate the significance of the CCA model. The CCA was conducted with "vegan" package v.2.4-0 (Oksanen et al. 2016) in the R software v. 3.5 ( Core Team 2017).

Diversity analysis. We calculated species richness as the number of species per plot as the response variable and we called this variable "all species". To analyze the role of the different environmental filters by species group, we also calculated species richness per plot for the most dominant genera separately (Quercus and Pinus). In addition, the genus Quercus was divided by sections, Quercus s.s (white oaks) and Lobatae (red oaks).

To analyze the importance of the environmental filters of the target species groups, we used generalized linear models (GLMs) with a Poisson distribution and a log-link function (Zuur et al. 2009). First, we included all explanatory variables by each group of variables (called "Full model") and then the model selection was based on maximum likelihood by using the sample-corrected Akaike Information Criterion (AICc). The best model was selected when variables were removed in a stepwise procedure from the full model, and the difference between the full model and the best model was more than $2(\triangle \mathrm{AICc}>2)$ (Burnham

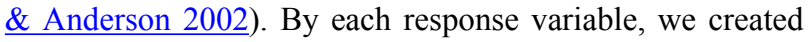
at least two models by the environmental group (G1, G2 and G3), the full model and the best model, obtaining a total of 30 models.

Residuals of GLMs were graphically explored to check model assumptions (i.e., distribution of residuals, independence, and homoscedasticity). We assessed spatial autocorrelation in model residuals by using Moran's I, which varies between 1 (positive autocorrelation) and -1 (negative autocorrelation). The expected Moran's I value when spatial autocorrelation is lacking is close to 0 (Borcard et al. 2011, Legendre \& Legendre 2012). Lastly, to determine the predictive power for each best model, we calculated a Pseudo $R^{2}$ with the following formula (Dobson 2002, Zuur et al. 2009):

(null deviance - residual deviance) / null deviance.

The GLM was calculated with the "stats" package v. 3.4.3 ( $\mathrm{R}$ Core Team 2017), the AICc was calculated with the “'AICcmodavg' package v. 2.2-2 (Mazerolle 2019) and spatial statistics were performed with the "spdep" package ver. 0.7-7 (Bivand \& Wong 2018) in the R software v. 3.5 (R Core Team 2017).

\section{Results}

Cluster analysis and IVI. A total of 63 tree species corresponding to 31 genera and 21 families were recorded, of which Fagaceae and Pinaceae together represented $50 \%$ of all species, with 22 (Quercus) and 10 species, 
respectively (nine species of Pinus and one of Abies). IVIs indicated that these two families represent $74.7 \%$ of the tree community, with the genus Pinus being the most important, accounting for $40.7 \%$, while the genus Quercus represented $34 \%$. The remaining $25.3 \%$ was contributed by trees belonging to the Ericaceae, Clethraceae, Fabaceae, Betulaceae and Theaceae families.

Cluster analysis allowed us to define eight groups, which we defined as species assemblages and later we classified according to their IVI and floristic composition into three forest types (i.e., oak, pine-oak and montane-cloud forests) at a Bray-Curtis similarity of 0.85 (Figure 2). The oak forest corresponded to two groups (Groups 1 and 2), while the pine-oak forest corresponded to four groups (Groups 3, 4, 5 and 6), and the cloud forest was represented by two groups (Groups 7 and 8) (Table 1).

In the oak forest, we found nine oak species that had IVIs values ranging between 7 and $51 \%$ and three species of Pinus. The dominant species were Quercus elliptica, $Q$. iltisii, $Q$. liebmannii, and $Q$. magnoliifolia. The other species that contributed substantially were Pinus oocarpa (8-21\%) and P. jaliscana (20\%). In the pine-oak forest, we found seven species of Pinus sharing their habitat with 14 species of Quercus. The most important Pinus species were Pinus douglasiana, $P$. jaliscana and $P$. oocarpa, with IVIs values ranging between 6 and $49 \%$, while the highest
IVIs among oak species were Quercus cualensis, Q. mexiae, $Q$. crassifolia, $Q$. scytophylla, $Q$. jonesii and Q. magnoliifolia, ranging between 8 and $34 \%$. In the montane cloud forest, we found four species of Pinus that presented IVIs values ranging between 6 and $21 \%$ sharing their habitat with Abies jaliscana, a species that contributed significantly to forest structure according to its IVI values (12-47 \%). The oak species had IVI values ranging between 6 and $17 \%$ with Quercus nixoniana (17\%) as the most important species, and species of the genera Cornus, Carpinus, Magnolia, Myrsine and Nectandra contributed with the remaining IVI values ranging between 5 and $16 \%$ (Table 1).

Species richness and elevation. The highest species richness was found in the 1,800 to $2,200 \mathrm{~m}$ range, where we recorded 38 species ( $60 \%$ of the total recorded species; Figure 3).

The elevational pattern for tree species richness showed a hump-shaped pattern, with a reduction at 1,600 $\mathrm{m}$, and a drastic increase up to $2,200 \mathrm{~m}$, at which point it decreases again until reaching the highest elevation. Elevational patterns for Pinus and Quercus also showed hump-shaped patterns. We recorded nine pine species, most of them in the 2,000 to $2,400 \mathrm{~m}$ range; the pines showed a gradual increase of species until reach 2,400 m; however, at the plot level the

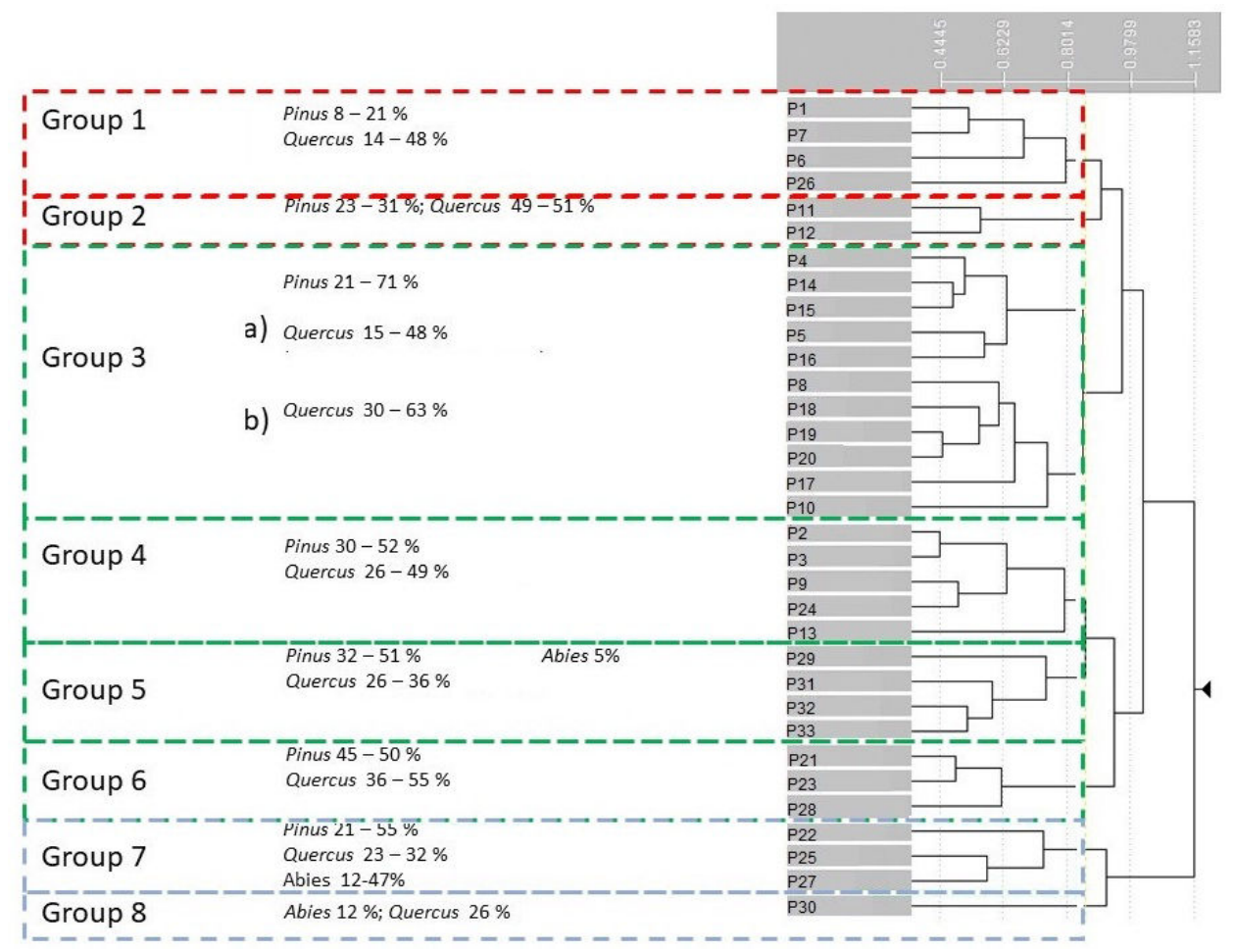

Figure 2. Dendrogram produced by the classification of vegetation samples based on the Bray-Curtis index. The genera along with the ranges of their importance value are shown. Groups 1 and 2 comprise the oak forests (red). Groups 3, 4, 5 and 6 comprise the pine-oak forests (green). Groups 7 and 8 comprise the cloud forests (blue). 
Table 1. Species assemblages classified into three forest types according to their importance value index (IVI) (\%) and floristic composition after a cluster analysis. Endemic species indicated by an asterisk $(*)$.

\begin{tabular}{|c|c|c|c|c|c|}
\hline Forest type & Elevation range $(\mathrm{m})$ & Group & Pinus species (IVI \%) & Quercus species (IVI \%) & Other species (IVI \%) \\
\hline \multirow[t]{9}{*}{ Oak forest } & $850-1208$ & 1 & P. devoniana (10) & Q. aristata (14) & Bejaria mexicana (5-10) \\
\hline & & & P. oocarpa $(8-21)$ & Q. elliptica $(14-21)$ & Byrsonima crassifolia (6-8) \\
\hline & & & & Q. glaucescens (7) & Clethra sp. (8-9) \\
\hline & & & & Q. liebmannii (32) & Conostegia xalapensis (5-14) \\
\hline & & & & Q. magnoliifolia (16-51) & Lysiloma acapulcense (13) \\
\hline & & & & & Ternstroemia lineata (10) \\
\hline & & 2 & P. jaliscana $*(20)$ & Q. iltisii $*(15-34)$ & Conostegia xalapensis (10) \\
\hline & & & P. oocarpa $(10-12)$ & Q. mexiae $*(8)$ & Clethra sp. (8-9) \\
\hline & & & & Q. resinosa $(14-17)$ & Ficus petiolaris (9) \\
\hline \multirow[t]{26}{*}{ Pine-Oak forest } & $892-2439$ & 3 & P. douglasiana (6-14) & Q. castanea $(11-15)$ & Acacia macracantha $(10)$ \\
\hline & & & P. jaliscana (11-38) & Q. cualensis $*(5-31)$ & Arbutus xalapensis (6-9) \\
\hline & & & P. oоcarpa (9-29) & Q. eduardii (10-11) & Bejaria mexicana (5-20) \\
\hline & & & & Q. elliptica $(10-21)$ & Clethra rosei (6-10) \\
\hline & & & & Q. jonesii (12) & Juniperus jaliscana* (5-6) \\
\hline & & & & Q. laeta $(8-18)$ & \\
\hline & & & & Q. magnoliifolia (12-34) & \\
\hline & & & & Q. mexiae (11-15) & \\
\hline & & & & Q. obtusata $(10)$ & \\
\hline & & & & Q. tuitensis $*(15-20)$ & \\
\hline & & 4 & P. douglasiana (15-20) & Q. castanea (14-16) & Acacia macracantha (25) \\
\hline & & & P. oocarpa $(14-32)$ & Q. jonesii (12-17) & Arbutus xalapensis (11) \\
\hline & & & P. devoniana (12-17) & Q. mexiae $(25-45)$ & Baccharis conferta $(8)$ \\
\hline & & & & Q. crassifolia (33) & Clethra rosei (8-9) \\
\hline & & & & Q. resinosa $(30)$ & Conostegia xalapensis (16-18) \\
\hline & & & & Q. scytophylla (10) & Gaultheria angustifolia $(8)$ \\
\hline & & 5 & P. douglasiana (9-12) & Q. calophylla $(5-10)$ & Abies jaliscana (5-6) \\
\hline & & & P. herrerae (10-12) & Q. castanea $(9-10)$ & Arbutus xalapensis (5-8) \\
\hline & & & P. oocarpa (14-20) & Q. mexiae $(5-10)$ & Clethra rosei (5-9) \\
\hline & & & P. devoniana (12-15) & Q. elliptica $(11)$ & Myrsine juergensenii (5) \\
\hline & & & P. pseudostrobus (20) & Q. obtusata $(7-17)$ & Prunus sp. $(5-7)$ \\
\hline & & & & Q. scytophylla (6-15) & Ternstroemia dentisepala (5-6) \\
\hline & & 6 & P. douglasiana (11-49) & Q. jonesii (20-25) & Arbutus xalapensis (7-8) \\
\hline & & & P. herrerae (22-29) & Q. crassifolia (19) & Cleyera integrifolia (15-16) \\
\hline & & & P. lumholtzii (11-20) & Q. obtusata (8-9) & \\
\hline & & & & Q. scytophylla (18-35) & \\
\hline \multirow[t]{9}{*}{ Cloud forest } & $2155-2507$ & 7 and 8 & P. ayacahuite (14-21) & Q. crassifolia $(6)$ & Abies jaliscana (12-47) \\
\hline & & & P. maximinoi $(22)$ & Q. laurina $(10-16)$ & Alnus acuminata (5) \\
\hline & & & P. pseudostrobus (11-22) & Q. martinezii (16) & Arbutus xalapensis (10-11) \\
\hline & & & P. douglasiana (6-10) & Q. nixoniana (17) & Carpinus tropicalis (9) \\
\hline & & & & Q. obtusata (7) & Cornus disciflora (14) \\
\hline & & & & Q. scytophylla (7-17) & Magnolia pacifica (5) \\
\hline & & & & Q. uxoris (8) & Myrsine juergensenii (15) \\
\hline & & & & & Nectandra salicifolia (16) \\
\hline & & & & & Ostrya virginiana (16) \\
\hline
\end{tabular}



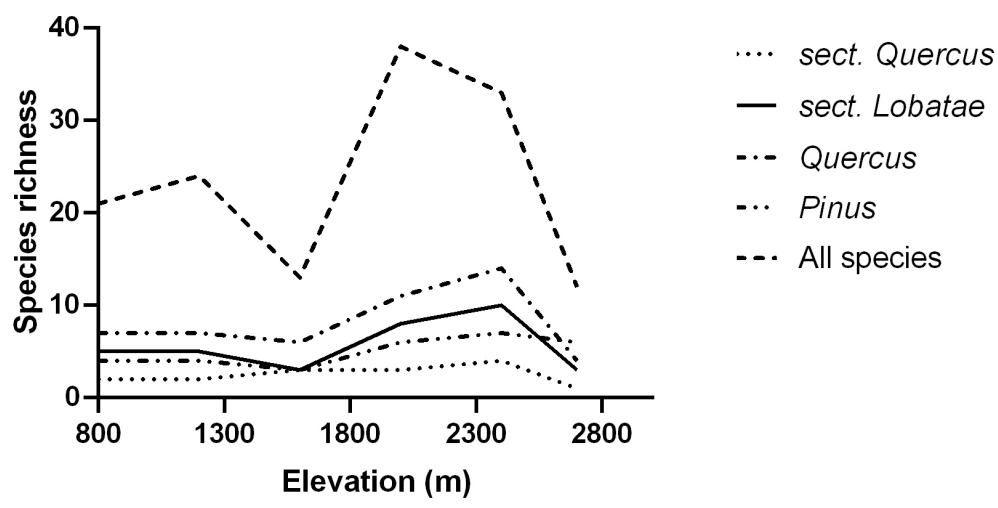

Figure 3. Elevational pattern of species richness for all species together, for the genera Quercus and Pinus, and for the sections Quercus s.s. and Lobatae of the genus Quercus.

largest pines species richness (four species) was located at $2,300 \mathrm{~m}$. For oaks we recorded 22 species (seven and 15 species for sections Quercus s.s. and Lobatae, respectively); this genus showed a gradual increase up to an elevation of $2,400 \mathrm{~m}$ and then a decrease to a minimum of four species at the highest elevations. At the plot level, the highest oak species richness (four species) was recorded at 1,900 m (one and three species for sections Quercus s.s. and Lobatae, respectively). At the section level, the section Quercus s.s. showed a slight increase at $1,600 \mathrm{~m}$ and remained stable up to $2,400 \mathrm{~m}$, beyond which elevation it showed a decrease in species richness; conversely sect. Lobatae showed a gradual increase in species richness with a small reduction at $1,600 \mathrm{~m}$ and, with a subsequent drastic increase until reaching $2,400 \mathrm{~m}$ and then a subsequent decrease. Tree species belonging to the families Lauraceae, Betulaceae and Theaceae were restricted to the cloud forest, thus displaying a very restricted elevational distribution in the area. However, the tree species that belong to the Ericacaeae (five species), Fabaceae, Theaceae (three species each) and Clethraceae (two species) showed low values of species richness, but a wider distribution along the elevational gradient.

Effect of the environment on species distributions. The results of the canonical correspondence analysis (CCA) showed that aridity index, the maximum temperature of the warmest month, the available inorganic nitrogen and total carbon were the most important variables, indicating that the species' distributions were mainly related to a gradient of soil nutrient content and water availability (Figure 4). The first two axes of the CCA explained 0.52 of total variation $(\mathrm{CCA} 1=0.29, P<0.001 ; \mathrm{CCA} 2=0.23$, $P<0.001)$. The first axis showed a soil nutrient gradient and the second axis a water availability gradient.

Individual GLMs were constructed for each group of species richness with each group of environmental variables
$(\mathrm{G} 1=$ climatic variables; G2 = relief factors; G3 = soil characteristics) and we reported the results of the best model obtained (Table 2; Appendix 2). Spatial autocorrelation in model residuals (Moran's I) ranged from -0.11 to 0.11 . For total richness (i.e., all species together), the soil variables explained $26 \%$ of the variation, among which $\mathrm{pH}$ and soil moisture (Sm) were the most important variables; in contrast, climatic variables only explained $18 \%$ of the variation where precipitation of the wettest quarter and the aridity index were the most important ones (Table 2). For Pinus richness, climatic variables explained $50 \%$ of the variation, with minimum temperature of the coldest month being the most important predictors, while soil and relief variables explained $33 \%$ and $33 \%$ of the variation, respectively. For the Quercus genus, soil variables explained $18 \%$ of the variation, among which soil moisture was the variable with the most significant contribution, while climatic variables explained $15 \%$. For the section Quercus s.s., the soil variables explained $16 \%$ of the variation of the species richness, where total nitrogen was the most important variable, while both climatic and relief variables explained a minute proportion of total variance ( $6 \%$ each). In turn, the climatic variables explained $28 \%$ of the variation the species richness of the Lobatae section, where precipitation of the wettest quarter was the most important variable (Table 2).

\section{Discussion}

The temperate forests in Mexico are distributed along the mountain ranges and are characterized by a high biological diversity under a large environmental heterogeneity expressed at different spatial scales (Challenger \& Caballero 1998, Rzedowski 2006). The high species richness in the Serranias Meridionales of Jalisco is mainly represented by the genera Pinus and Quercus, which together account for $49 \%$ of total species richness and $74 \%$ 


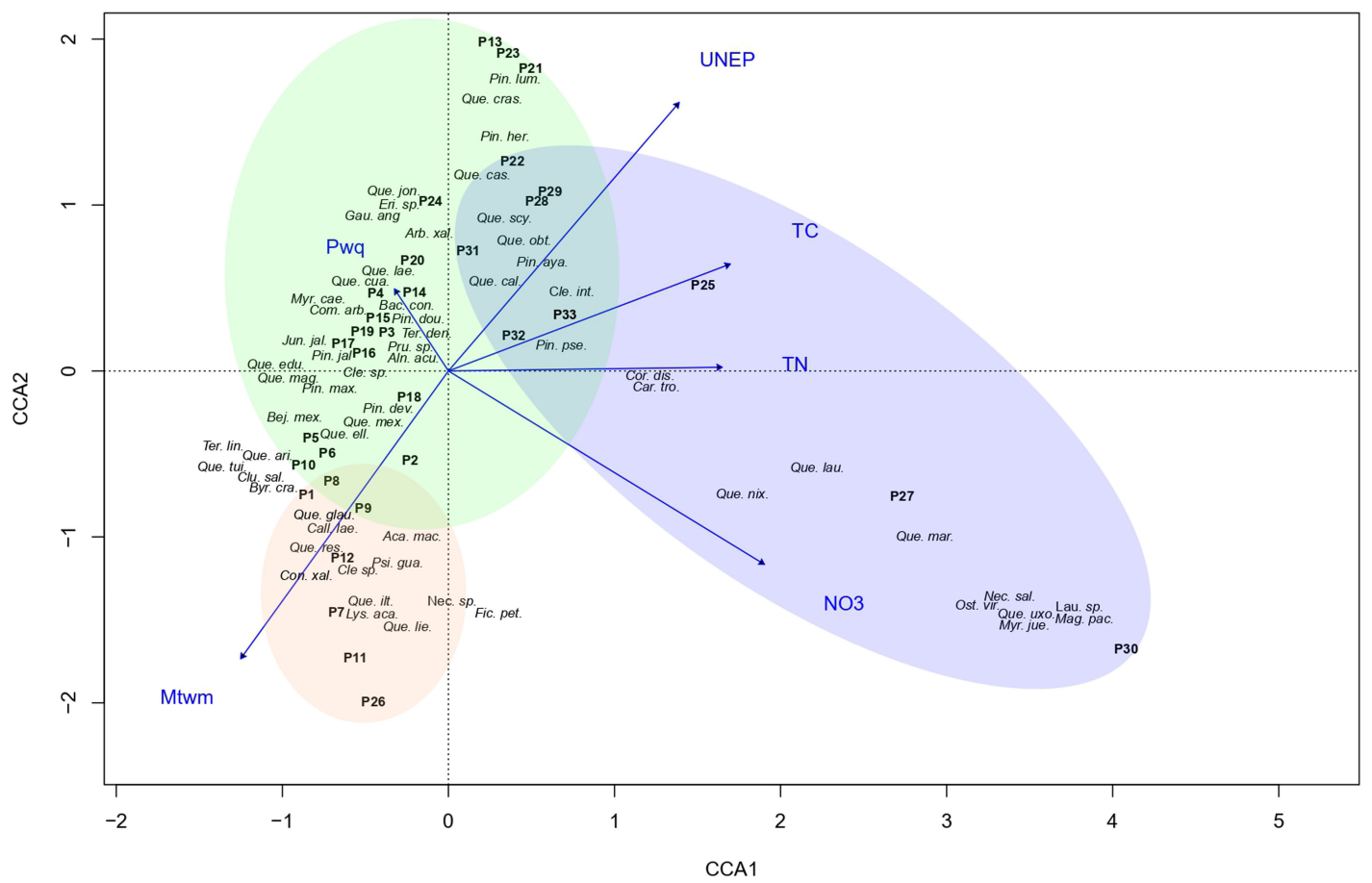

Figure 4. Sample ordination produced by the canonical correspondence analysis. The colored ellipses represent the three main forest groups detected in the cluster analysis encompassing the sampling plots (P1 to P33); red, oak forest; green, pine-oak forest; blue, cloud forest. UNEP, UNEP aridity index; Mtwm, Maximum temperature of warmest month; Pwq, Precipitation of wettest quarter; NO3, Nitrate; TC, Total Carbon and TN, Total Nitrogen. Abbreviations of the species use the first three letters of the genus and the first three letters of the species name. Abies jaliscana, Abi jal; Acacia macracantha, Aca mac; Arbutus xalapensis, Arb xal; Baccharis conferta, Bac con; Bejaria mexicana, Bej mex; Alnus acuminata, Aln acu; Byrsonima crassifolia, Byr cra; Calliandra laevis, Cal lae; Carpinus tropicalis, Car tro; Ostrya virginiana, Ost vir; Clethra rosei, Cle ros; C. hartwegii, Cle har; Cleyera integrifolia, Cle int; Clusia salvinii, Clu sal; Comarostaphylis arbutoides, Com arb; Conostegia xalapensis, Con xal; Cornus disciflora, Cor dis; Juniperus jaliscana, Jun jal; Ericaceae sp., Eri sp.; Ficus petiolaris, Fic pet; Gaultheria angustifolia, Gau ang; Lauraceae sp., Lau sp.; Lysiloma acapulcense, Lys aca; Magnolia pacifica, Mag pac; Myrica cerifera, Myr cer; Myrsine juergensenii, Myr jue; Nectandra salicifolia, Nec sal; Nectandra sp., Nec sp.; Pinus ayacahuite, Pin aya; P. devoniana, Pin dev; P. douglasiana, Pin dou; P. herrerae, Pin her; P. jaliscana, Pin jal; P. lumholtzii, Pin lum; P. oocarpa, Pin ooc; P. pseudostrobus, Pin pse; P. maximinoi, Pin max; Prunus sp., Pru sp.; Psidium guajava, Psi gua; Quercus aristata, Que ari; Q. calophylla, Que cal; Q. castanea, Que cas; Q. jonesii, Que jon; Q. mexiae, Que mex; Q. crassifolia, Que cra; Q. cualensis, Que cua; Q. eduardii, Que edu; Q. elliptica, Que ell; Q. glaucescens, Que gla; Q. iltisii, Que ilt; Q. laeta, Que lae; Q. laurina, Que lau; Q. liebmannii, Que lie; Q. magnoliifolia, Que mag; Q. martinezii, Que mar; Q. nixoniana, Que nix; Q. obtusata, Que obt; Q. resinosa, Que res; Q. scytophylla, Que scy; Q. tuitensis, Que tui; $Q$. aff. uxoris, Que uxo; Ternstroemia lineata, Ter lin; T. dentisepala, Ter den.

of the IVI in the study region. The remaining species richness is distributed among the families Ericaceae, Clethraceae, Fabaceae, Betulaceae, Theaceae and Magnoliaceae, showing that the Serranías Meridionales of Jalisco hosts a high phylogenetic richness.

The cluster analysis identified eight groups, with a clear dominance of several Pinus and Quercus species, that we classify according to their IVI and floristic composition into three forest types (i.e., oak, pine-oak and montane-cloud forests) occurring along two main environmental gradients (nutrient soil conditions $\left[\mathrm{NO}_{3}^{-}\right]$, and water availability, as measured by the UNEP aridity index). The oak forest showed a floristic composition dominated by deciduous oaks, with the presence of drought tolerant species or xeric affinity registered in other oak forest (Aguilar-Romero et al. 2016, de la Riva et al. 2019). The pine-oak forest showed a floristic composition dominated by a high diversity of red oaks and pines, with the presence of several temperate species typical of Mexican temperate forest (Challenger \& Caballero 1998, Rzedowski 2006). The montane-cloud forest hosts several tropical and temperate tree species, which has been suggested that the area could be a Tertiary 
Table 2. Results of the individual GLM for each group of variables. Model selection (best model) was based on the best-supported models according to maximum likelihood (smallest AICc) and $(\triangle \mathrm{AICc}>2)$. Variables in bold font are those that show statistical significance $(P<0.05)$. Mtwm, Maximum temperature of warmest month; Mtcm, Minimum temperature of coldest month; Pwq, Precipitation of wettest quarter of the year; Tar, Temperature annual range; Pcq, Precipitation of coldest quarter; UNEP, aridity index; Elev, Elevation; Slp, slope steepness; Asp, aspect; TC, Total Carbon; TN, Total Nitrogen; TP, Total Phosphorus; $\mathrm{NO}_{3}^{-}$, Nitrate; pHs, soil pH and Sm, soil moisture.

\begin{tabular}{|c|c|c|c|c|c|c|}
\hline \multirow[t]{2}{*}{ Group of variables } & & & \multicolumn{4}{|c|}{ Full model Best model } \\
\hline & & & $\mathrm{AICc}$ & AICc & $\triangle \mathrm{AICc}$ & Pseudo $R^{2}$ \\
\hline \multirow[t]{7}{*}{ Climatic } & \multicolumn{6}{|c|}{ Full model (Mtwm, Mtcm, Pwq, Tar, Pcq, UNEP) } \\
\hline & \multicolumn{6}{|l|}{ Best model } \\
\hline & All species & Pwq, UNEP & 175.1 & 173 & 2.1 & 0.18 \\
\hline & Pinus & Mtcm & 110.5 & 97.89 & 12.61 & 0.50 \\
\hline & Quercus & Pwq, Pcq, UNEP & 116.4 & 112.3 & 4.1 & 0.15 \\
\hline & Lobatae & Pwq, Pcq, UNEP & 95.97 & 91.06 & 4.91 & 0.28 \\
\hline & Quercus s.s. & Mtcm, Tar, Pcq & 76.93 & 66.71 & 10.22 & 0.06 \\
\hline
\end{tabular}

Relief

Full model (Asp, Elev, Slp)

\section{Best model}

$\begin{array}{llcccc}\text { All species } & \text { Asp, Elev, Slp } & 175.85 & - & - & 0.06 \\ \text { Pinus } & \text { Elev } & 103.06 & 98.47 & 4.59 & 0.33 \\ \text { Quercus } & \text { Asp, Elev, Slp } & 112.76 & - & - & 0.12 \\ \text { Lobatae } & \text { Asp } & 92.24 & 88.31 & 3.93 & 0.08 \\ \text { Quercus s.s. } & \text { Asp, Slp } & 66.71 & 63.97 & 2.74 & 0.06\end{array}$

Soil

Full model (TC, TN, TP, NO3-, pHs, Sm)

Best model

\begin{tabular}{llcccc} 
All species & pHs,, Sm & 174.95 & 165.08 & 9.87 & 0.26 \\
Pinus & TC, NO3- & 112.9 & 100.86 & 12.04 & 0.33 \\
Quercus & TC, pHs, Sm & 120.89 & 112.24 & 8.65 & 0.18 \\
Lobatae & TC, pHs & 102.96 & 90.96 & 12 & 0.06 \\
Quercus s.s. & TN & 77.01 & 61.4 & 15.61 & 0.16 \\
\hline
\end{tabular}

refuge being the most important forest in terms of richness and floristic composition for western Mexico (VargasRodríguez et al. 2010, 2015).

The eight species assemblages included red and white oaks, which could indicate a phylogenetic overdispersion, which has been suggested as an explanation for how high oak diversity is maintained at the community level (Cavender-Bares et al. 2004). Oaks and pines have a temperate Nearctic origin and had a subsequent diversification in Mexico in montane regions, with 161 and 49 species, respectively (Valencia-Á. 2004, Gernandt \& Pérez de la Rosa 2014, Hipp et al. 2018). The high diversity and high IVI values of both genera suggest that they play an important role in the ecosystem function in these temperate forest; however, more studies at the functional level are needed to understand the role of both genera in the ecosystem functioning (de la Riva et al. 2019).

The Serranías Meridionales of Jalisco is a biodiversity hotspot with a high number of species including several endemic species of Quercus and Pinus, among others. This could be one of the regions with the highest oak species richness in the world with 22 species recorded. However, various floristic studies and new descriptions in the region could increase this number to 30 oak species (MoralesSaldaña 2017, González-Villarreal 2018), indicating that this region hosts $14 \%$ of the species richness at country level (161 species), $49 \%$ of state species richness (> 45 species). Comparing with other regional studies in Mexico, Ramírez-Toro et al. (2017) found that in the state of Oaxaca (the richest state in oak species with 52 species), 
the physiographic provinces of the Sierra Madre de Oaxaca and Montañas y Valles del Occidente could be the richest regions in oak species in the country, with 38 and 29 species, respectively. Furthermore, compared to the species richness with other countries, the Serranías Meridionales of Jalisco has three times as many oak species as there are in Canada (10 species), and nearly the same as Central America (34) (Nixon 2006), India (35) (Negi \& Naithani 1995) or Europe (30) (Xu et al. 2019).

Elevational patterns. We expected species richness to decrease towards higher elevations, but we found that the tree species richness presented a hump-shaped pattern in the Serranías Meridionales of Jalisco. Several studies of species richness in plants have revealed 'hump-shaped' patterns along elevational gradients such as ferns (Kluge et al. 2006, Kessler et al. 2011), epiphytes (Krömer et al. 2005), oaks (Morales-Saldaña 2017) and vascular plants (Kessler 2000), which seems to be the most frequent, but not the only one. The potential causes underlying the hump-shaped pattern of species richness have been discussed extensively, and it has been observed that the relationship between species richness and elevation varies greatly with the scale of the extent and if the full elevational gradient was surveyed or when the lower or upper limits were omitted (Nogués-Bravo et al. 2008).

It is important to recognize that our study encompassed a partial elevation range from 800 to $2,600 \mathrm{~m}$, which imposes a limit to our interpretations for the full gradient.

The hump-shaped pattern in the Serranías Meridionales of Jalisco may be a consequence of the overlap of species of tropical and temperate affinities, reflecting their ecological characteristics, due to the local adaptation in mountainous areas as tolerance to cold temperatures and functional strategies to avoid water stress (Cavender-Bares \& Holbrook 2001, Koehler et al. 2012).

The Quercus and Pinus species as dominant at midelevations has been explained by their ability to disperse and had undergone extensive adaptative radiation and the capacity to partitioning resources effectively (HernándezLópez 1995, Vázquez-García \& Givnish 1998). In addition, an important contribution to the total species richness at mid-elevations was the presence of typical cloud forest elements like Magnolia pacifica, Alnus acuminata and several Lauraceae species, among others. Conversely, we observed a decrease in the species richness at 1,600 m dominated by white oaks as Quercus magnoliifolia and Q. resinosa, both of which are characteristic of drier areas.

Other studies on species richness along elevational gradients in Mexico have reported a decreasing pattern of vascular plants (Vázquez-García \& Givnish 1998, SalasMorales \& Meave 2012) or a hump-shaped pattern (Sánchez-González \& López-Mata, 2005). Some of the discrepancies in assessing spatial richness patterns between different studies could be sampling effort (i.e., plot size and number), selection of growth forms (i.e., trees, shrubs, herbs and epiphytes) and partial or total analysis across the elevational gradient (Lomolino 2001, Nogués-Bravo et al. 2008, McCain \& Grytnes 2010). In our study, the collecting effort was homogeneous, but we analyzed a partial elevational gradient, so it would be important to perform the complete elevation gradient and see if the same elevation pattern is maintained.

Ecological filtering in Serranias Meridionales of Jalisco. In plant communities, it has been suggested that species with similar distributions respond similarly to environmental filters across ecological gradients (Ferrer-Castán \& Vetaas 2003). In this context, mountain regions are good models to assess whether taxa respond differently to environmental filters (Jiménez-Alfaro et al. 2014). Plant species distribution over elevational gradients can be affected in diverse ways by climate, relief (i.e., slope aspect and inclination) or soil characteristics (i.e., soil water retention and heterogeneous distribution of fertility) (Pickering \& Green 2009, Scherrer \& Körner 2011, Jiménez-Alfaro et al. 2014, Estrada-Castillón et al. 2015). In our study, the soil and climatic variables explained the most of the variance in the different groups of species analyzed. When we analyzed the species richness for all species together, the soil variables, including $\mathrm{pH}$ and soil moisture, contributed with the most variance explained by the model $(26 \%)$, followed by the climatic variables (18\%). In general, climatic variables are the main factors that determine large scale patterns of species richness (Francis \& Currie 2003, Götzenberger et al. 2011, de Bello et al. 2012).

In the lowland Neotropics, species richness of woody plants increases with the increment of annual precipitation and the decrease of the dry season length (Gentry 1988, Currie 1991, Clinebell et al. 1995, Francis \& Currie 2003). However, studies at regional scale in temperate species showed that soil variables were more important than climatic variables (Diekmann et al. 2015, Walthert \& Meier 2017). At local scales, soil traits like soil $\mathrm{pH}$ are key drivers of plant species richness (Pärtel 2002, Dubuis et al. 2013, Rao et al. 2018). In fact, our results indicate that soil moisture and soil $\mathrm{pH}$ could be important factors influencing species richness patterns at regional scale. Several studies at local scales (mostly in tropical forest) have reported that plant species richness and density increase with soil fertility (Grime 1979, Pausas \& Austin 2001), although the generality of this conclusion has been questioned (Tuomisto et al. 2014).

The high species richness of the genus Pinus in Mexico is explained by the existence of two diversification centers, one of them located in the Trans-Mexican Volcanic Belt, 
and the second in north-eastern Mexico (Farjon \& Styles 1997), along with migration processes that resulted in regions with high endemism and species richness. Therefore, Mexico is considered a secondary center of diversification and richness for this genus, with 49 (40\%) of the approximately 120 species in the world (Gernandt \& Pérez de la Rosa 2014).

The variable group that mostly contributed to Pinus richness was the climatic (50\%), followed by soil (33\%) and relief $(33 \%)$ variables. Also, the importance of temperature and precipitation, and more particularly of its seasonality, were the primary factors determining the vegetation types and functional responses, due to thermal conditions in the growing season (Tang \& Fang 2006, Zhou et al. 2016). Seasonal patterns in temperature and precipitation influence seed germination, seedling growth, productivity, phenology and litterfall production, all of which has an impact on the survival and establishment of plants in mountainous areas (Tang \& Fang, 2006, SalamonAlbert et al. 2017).

The genus Quercus occurs across gradients of fertility, fire regimen and soil moisture (Cavender-Bares et al. 2004). Soil moisture was an important contributor in our analysis $(18 \%)$ in relation to species richness in this genus, followed by climatic variables related to precipitation (15\%). In Northern Florida, the soil moisture gradient was shown to explain part of the variation of the hydraulic properties of the species, which in turn are correlated with the distribution of individual species and their success in their respective habitats (Cavender-Bares \& Holbrook 2001, Cavender-Bares et al. 2004), thus reflecting the great ability of oaks to adapt to different climatic and moisture gradients and promoting their occurrence in diverse habitats and climates that range from dry to temperate and subtropical forests (Valencia-Á. 2004, Hipp et al. 2018). The high species richness and high endemism of Mexican oaks have been highlighted by Manos et al. (1999), Nixon (1993), Valencia-Á. (2004), Torres-Miranda et al. (2011, 2013) and Rodríguez-Correa et al. (2015). This extraordinary diversification has been explained as a result of their ability to establish along moisture gradients in mountainous areas as the Mexican Transition Zone (Nixon 1993, MoralesSaldaña 2017, Hipp et al. 2018).

When dissecting the genus Quercus into its two sections, we found several differences. In the case of section Lobatae, the climatic variables contribute with the largest variance explained by the model $(28 \%)$, followed by the soil variables $(6 \%)$ for species richness. The results showed an increase in richness in those areas with higher precipitation within the warmest quarter of the year, which are not necessarily the areas receiving the highest annual rainfall. Particularly, seasonal water availability through precipitation has an impact on variables such as soil moisture (Concilio et al. 2009, Salamon-Albert et al. 2017). Several studies on the distribution of oak species conducted at regional scales have suggested that species of section Quercus s.s. are more resistant to drought than section Lobatae (Abrams 1990, 2003, Nixon 1993, Aranda et al. 2014). However, through a study conducted across an aridity gradient in central Mexico, Aguilar-Romero et al. (2017) did not support this idea because they found that physiological components of the water-use strategy did not differ between oak sections, although they suggest a higher resistance to water stress in red than in white oaks.

Quercus s.s. species richness was primarily affected by soil traits such as total nitrogen soil content $(16 \%)$. This could be due to the ability of some white oaks to improve soil conditions; for example, Chávez-Vergara et al. (2015) found that $Q$. deserticola (sect. Quercus s.s.) produced more nutrient-rich litter with higher nitrogen concentration, thus enhancing microbial activity in the forest litter and soil fertility to the benefit of other coexisting species like Q. castanea (sect. Lobatae).

In this study, soil and climatic variables explained most of the variance in tree species richness of the different species groups analyzed. Temperature and precipitation across the elevational gradient affect numerous soil processes and properties; however, plant species also affect soil properties such as nutrient status, mainly by speciesspecific litter input having a deterministic impact on the survival and establishment of species assemblages (Walthert \& Meier 2017, Salamon-Albert et al. 2017). In the Serranías Meridionales of Jalisco, seasonal patterns in temperature and precipitation, the length of the nutrient gradient, the influence of $\mathrm{pH}$ on nutrient availability, and the correlation with soil moisture may all influence the shape of the response of species richness. The variation was not fully explained by the environmental filters examined, which suggests that other factors, such as interactions among species, might also be influencing their distribution.

Implications for conservation. In Mexico deforestation rates are high; during the last decade, the Food and Agriculture Organization (FAO) classified Mexico in the seventh place in the world with the yearly average surface deforested reaching almost one million hectares (Eguiluz-Piedra 2003, Rosete-Vergés et al. 2014). This alarming rate of forest cover loss urgently requires strong efforts to protect areas that feature high species richness and endemism, such as the Serranías Meridionales of Jalisco. Implementing a general protection and conservation program is needed to preserve not only species richness and endemism but all ecological processes that occur at different spatial scales. While conducting fieldwork for this study, we witnessed illegal tree cutting and forest clearing in this important biodiversity hotspot. The corruption of authorities is the main obstacle to preserve and protect the biodiversity in Mexico. 


\section{Acknowledgements}

We thank to R. Velázquez-Durán for soil nutrient analyses. We also thank to R. Aguilar-Romero, A. PérezPedraza, S. Morales, C. Miguel-Talonia, A. Noyola, M. Mata, Fito and G. López-Segoviano for assistance in the field work. We thank S. Valencia-Á. and D. Gernandt for species identification. We thank to two anonymous reviewers for helpful suggestions that improved an earlier version of this manuscript. We especially thank to people at Ejido Provincia, El Cuale, La Cumbre and county of Talpa de Allende for access and facilities to the study site. Funding was provided by CONACYT CVU/Grant (440679/271063) to M.A.-N.; DGAPA PAPIIT IV, 201016 to KO, and IA208218 to ATM. This paper constitutes a partial fulfillment of the Graduate Program in Biological Sciences of the National Autonomous University of Mexico (UNAM) for M. Arenas-Navarro.

\section{Literature cited}

Abrams MD. 1990. Adaptations and responses to drought in Quercus species. Tree Physiology 7: 227-238. DOI: https://doi.org/10.1093/treephys/7.1-2-3-4.227

Abrams MD. 2003. Where has all the white oaks gone? BioScience 53: 927-939. DOI: https://doi.org/10.16 41/0006-3568(2003)053[0927:WHATWO]2.0.CO;2

Aguilar-Romero R, García-Oliva F, Pineda-García F, Torres I, Peña-Vega E, Guilardi A, Oyama K. 2016. Patterns of distribution of nine Quercus species along an environmental gradient in a fragmented landscape in central Mexico. Botanical Sciences 94: 471-482. DOI: https://doi.org/10.17129/botsci.620.

Aguilar-Romero R, Pineda-García F, Paz H, GonzálezRodríguez A, Oyama K. 2017. Differentiation in the water-use strategies among oak species from central Mexico. Tree Physiology 37: 915-925. DOI: https:// doi.org/10.1093/treephys/tpx033

Aranda I, Ramírez-Valiente JA, Rodríguez-Calcerrada J. 2014. Características funcionales que influyen en la respuesta a la sequía de las especies del género Quercus: variación inter- e intra-específica. Ecosistemas 2: 27-36. DOI: https://doi.org/10.7818/ECOS.2014.23-2.05

Arriaga-Cabrera L, Espinoza-Rodríguez JM, AguilarZúñiga C, Martínez-Romero E, Gómez-Mendoza L, LoaLoza E, coord. 2000. Regiones Terrestres Prioritarias de México. México, DF: Comisión Nacional para el Conocimiento y Uso de la Biodiversidad. ISBN: 970-9000-16-0

Arriaga-Cabrera L, Aguilar-Sierra V, Alcocer-Durand J. 2002. Aguas Continentales y Diversidad Biológica de México. México, DF: Comisión Nacional para el Conocimiento y Uso de la Biodiversidad. ISBN: 970-9000-15-2
Belbin L. 1995. A multivariate approach to the selection of biological reserves. Biodiversity and Conservation 4: 951-963. DOI: https://doi.org/10.1007/BF00058206

Belbin L. 2003. PATN A Revised USER's Guide. Canberra, Australia: CSIRO Division of Wildlife and Ecology.

Beniston M, Díaz HF, Bradley RS. 1997. Climatic change at high elevation sites: an overview. Climatic Change 36: 233-251. DOI: https://doi.org/10.1023/A:1005380714 349

Bivand RS, Wong DW. 2018. Comparing implementations of global and local indicators of spatial association. Test 27: 716-748. DOI: https://doi.org/10.1007/s11749-0180599-x

Borcard D, Gillet F, Legendre P. 2011. Numerical Ecology with R. New York: Springer. ISBN: 978-1441979759; DOI: $\underline{\text { https://doi.org/10.1007/978-1-4419-7976-6 }}$

Bremmer JM. 1996. Nitrogen-total. In: Sparks D, Page AL, Helmke PA, Loerppert RGH, Soltanpour PN, Tabatabai MA, Jhonson CT, Sumner ME, eds. Methods of Soil Analysis. Part 3. Chemical Analysis. Madison: Soil Science Society of American and American Society of Agronomy, pp. 1085-1121. DOI: https://doi.org/10.2136/ $\underline{\text { sssabookser5.3 }}$

Burnham KP, Anderson DR. 2002. Model Selection and Multimodel Inference: A Practical Information-Theoretic Approach. New York: Springer. ISBN 10: 0-387-95364-7; ISBN-13: 978-0387953649

Cavender-Bares J, Holbrook NM. 2001. Hydraulic properties and freezing-induced cavitation in sympatric evergreen and deciduous oaks with contrasting habitats. Plant, Cell and Environment 24: 1243-1256. DOI: https://doi.org/10.1046/j.1365-3040.2001.00797.x

Cavender-Bares J, Kitajima K, Bazzaz FA. 2004. Multiple trait associations in relation to habitat differentiation among 17 Floridian oak species. Ecological Monographs 74: 635-662. DOI: https://doi.org/10.1890/03-4007

Cavender-Bares J, Kothari S, Meireles JE, Kaproth MA, Manos PS, Hipp AL. 2018. The role of diversification in community assembly of the oaks (Quercus L.) across the continental U.S. American Journal of Botany 105: 565-586. DOI: https://doi.org/10.1002/ajb2.1049

Challenger A, Caballero J. 1998. Utilización y Conservación de los Ecosistemas Terrestres de México: Pasado, Presente y Futuro. México, DF: Comisión Nacional para el Concimiento y Uso de la Biodiversidad. ISBN 10: 970-9000-02-0; ISBN 13: 9789709000023

Chávez-Vergara BM, González-Rodríguez A, Etchevers JD, Oyama K, García-Oliva F. 2015. Foliar nutrient resorption constrains soil nutrient transformations under two native oak species in a temperate deciduous forest in Mexico. European Journal of Forest Research 134: 803-817. DOI: https://doi.org/10.1007/s10342-015-08 $\underline{91-1}$ 
Clinebell RR, Phillips OL, Gentry AH, Stark N, Zuuring H. 1995. Prediction of neotropical tree and liana species richness from soil and climatic data. Biodiversity and Conservation 4: 56-90. DOI: https://doi.org/10.1007/ $\underline{B F 00115314}$

Colwell RK, Rahbek C, Gotelli NJ. 2004. The mid-domain effect and species richness patterns: What have we learned so far? The American Naturalist 163: E1-E23. DOI: https://doi.org/10.1086/382056

Concilio M, Chen J, Ma S, North M. 2009. Precipitation drives interannual variation in summer soil respiration in a Mediterranean-climate, mixed-conifer forest. Climatic Change 92: 109-122. DOI: https://doi.org/10.1007/s105 84-008-9475-0

Cuervo-Robayo AP, Téllez-Valdés O, Gómez-Albores MA, Venegas-Barrera CS, Manjarrez J, Martínez-Meyer E. 2014. An update of high-resolution monthly climate surfaces for Mexico. International Journal of Climatology 34: 2427-2437. DOI: https://doi.org/10.10 $\underline{02 / j o c .3848}$

Cuevas-Guzmán R, González-Gallegos JG, HernándezLópez L, Íñiguez-Dávalos LI, Jardel-Peláez E, Rodríguez-Moreno P, Santiago-López AL. 2010. Sierra Madre del Sur y franja Neovolcánica de Jalisco. In: Toledo T, coord. El Bosque Mesófilo de Montaña en México: Amenazas y Oportunidades para su Conservación y Manejo Sostenible. México, DF: Comisión Nacional para el Concimiento y Uso de la Biodiversidad, pp 68-79. ISBN: 978-607-7607-35-9

Currie DJ. 1991. Energy and large-scale patterns of animaland plant-species richness. The American Naturalist 137: 27-49.

Curtis J, Mcintosh R. 1951. An upland forest continuum in the prairie-forest border region of Wisconsin. Ecology 32: 476-496. DOI: https://doi.org/10.2307/1931725

de Bello F, Lavorel S, Lavergne S, Albert CH, Boulangeat I, Mazel F, Thuiller W. 2012. Hierarchical effects of environmental filters on the functional structure of plant communities: A case study in the French Alps. Ecography 36: 393-402. DOI: https://doi.org/10.1111/ j.1600-0587.2012.07438.x

de la Riva E.G, Arenas-Navarro M, Villar R, García-Oliva F, Oyama K. 2019. El papel de la evapotranspiración en la distribución funcional foliar de 28 especies del género Quercus de España y México. Ecosistemas 28: 199-207. DOI: https://doi.org/10.7818/ECOS.1803

Diekmann M, Michaelis J, Pannek A. 2015. Know your limits - The need for better data on species responses to soil variables. Basic and Applied Ecology 16: 563-572. DOI: https://doi.org/10.1016/j.baae.2015.08.010

Dobson AJ. 2002. Introduction to Generalized Linear Models. Boca Raton, Florida: CRC Press. ISBN: $1-58488-165-8$
Dubuis A, Giovanettina S, Pellissier L, Pottier J, Vittoz P, Guisan A. 2013. Improving the prediction of plant species distribution and community composition by adding edaphic to topo-climatic variables. Journal of Vegetation Science 24: 593-606. DOI: https://doi.org/ 10.1111/jvs. 12002

Eguiluz-Piedra T. 2003. The Present Situation of Mexican Forestry. FAO Advisory. Committee on Paper and Wood Products. Report of the 44th Session Oaxaca, Mexico. http://www.fao.org/3/Y4829E/y4829e09.htm\#P3829 31 4666 (accessed May 18, 2018)

ESRI [Environmental Systems Research Institute] 2013. ArcGIS 10.2. Redlands, California. http://www.esri.com/ software/arcgis (accessed January 25, 2017).

Estrada-Castillón E, Arévalo JR, Villarreal-Quintanilla JA, Salinas-Rodríguez M, Encina-Domínguez J, GonzálezRodríguez H, Cantú-Ayala C. 2015. Classification and ordination of main plant communities along an altitudinal gradient in the arid and temperate climates of northeastern Mexico. The Science of Nature 102: 59. DOI: https://doi.org/10.1007/s00114-015-1306-3

Farjon A, Styles BT. 1997. Pinus (Pinaceae). Flora Neotropica. Monograph 75. New York: The New York Botanical Garden. ISBN: 0-89327-411-9

Ferrer-Castán D, Vetaas OR. 2003. Floristic variation, chorological types and diversity: Do they correspond at broad and local scales? Diversity and Distributions 9: 221-235. DOI: https://doi.org/10.1046/j.1472-4642.2003. 00009.x

Fiedler K, Beck E. 2008. Investigating gradients in ecosystem analysis. In: Beck E, Bendix J, Kottke I, Makeschin F, Mosandl R, eds. Gradients in a Tropical Mountain Ecosystem of Ecuador. Berlin: Springer, pp. 49-54. ISBN: 978-3-540-73526-7 DOI: https://doi.org/ $\underline{10.1007 / 978-3-540-73526-7}$

Francis AP, Currie DJ. 2003. A globally consistent richness-climate relationship for Angiosperms. The American Naturalist 161: 523-536. DOI: https://doi.org/ $\underline{10.1086 / 368223}$

Gentry AH. 1988. Changes in plant community diversity and floristic composition on environmental and geographical gradients. Annals of the Missouri Botanical Garden 75: 1-34. DOI: https://doi.org/10.2307/2399464

Gernandt DS, Pérez de la Rosa JA. 2014. Biodiversidad de Pinophyta (coníferas) en México. Revista Mexicana de Biodiversidad 85: 126-133. DOI: https://doi.org/10.7550/ $\underline{\mathrm{rmb} .32195}$

González-Gallegos JG, Castro-Castro A. 2012. Salvia cualensis and Salvia cualensis var. perezii (Lamiaceae), two new taxa from the Sierra de El Cuale, Jalisco, Mexico. Phytotaxa 74: 47-58. DOI: https://doi.org/ $\underline{10.11646 / \text { phytotaxa.74.1.5 }}$ 
González-Villarreal LM. 1986. Contribución al Conocimiento del Género Quercus (Fagaceae) en el Estado de Jalisco. Guadalajara, México: Instituto de Botánica, Universidad de Guadalajara. ISBN: 968-895-027-0

González-Villarreal LM. 2018. Dos nuevas especies de encinos (Quercus: Fagaceae), adicionales para la flora de Jalisco y áreas colindantes, en el Occidente de México. Ibugana 9: 47-71.

Götzenberger L, de Bello F, Bråthen KA, Davison J, Dubuis A, Guisan A, Lepš J, Lindborg R, Moora M, Pärtel M, Pellissier L, Pottier J, Vittoz P, Zobel K, Zobel M. 2011. Ecological assembly rules in plant communitiesapproaches, patterns and prospects. Biological Reviews 87: 111-127. DOI: https://doi.org/10.1111/j.1469-185x. 2011.00187.x

Grime JP. 1979. Plant Strategies and Vegetation Processes. New York: John Wiley \& Sons, Ltd. ISBN: 978-0-470-85040-4

Hawkins BA, Field R, Cornell HV, Currie DJ, Guégan JF, Kaufman DM, Kerr JT, Mittelbach GG, Oberdorff T, O'Brien EM, Porter EE, Turner RG. 2003. Energy, water, and broad scale geographic patterns of species richness. Ecology 84: 3105-3117. DOI: https://doi.org/10.1890/ 03-8006

Hernández-López L. 1995. La flora endémica de la sierra de Manantlán, Jalisco-Colima, México: observaciones preliminares. In: Vázquez-García JA, Cuevas R, Cochrane T, eds. Flora de Manantlán. Fort Worth, Texas: Sida Botanical Miscellany 13 and Botanical Research Institute of Texas, pp. 72-81. ISSN: 0833-1475

Hipp AL, Manos PS, González-Rodríguez A, Hahn M, Kaproth M, McVay JD, Valencia-Avalos S, CavenderBares J. 2018. Sympatric parallel diversification of major oak clades in the Americas and the origins of Mexican species diversity. New Phytologist 217: 439-452. DOI: https://doi.org/10.1111/nph.14773

Huffman EWD. 1977. Performance of a new automatic carbon dioxide coulometer. Microchemical Journal 22: 567-573. DOI: https://doi.org/10.1016/0026-265X(77) 90128-X

Hutchinson MF. 2006. Anusplin Version 4.36 User Guide. Canberra, Australia: Centre for Resource and Environmental Studies. ISBN: 0867405120

INEGI [Instituto Nacional de Estadística y Geografía]. 2007. Carta Edafológica Serie II. Escala 1:250 000 Puerto Vallarta F13-11. https://www.inegi.org.mx/temas/ edafologia/default.html\#Mapa (accessed April 4, 2019).

Jiménez-Alfaro B, Marcenó C, Bueno Á, Gavilán R, Obeso JR. 2014. Biogeographic deconstruction of alpine plant communities along altitudinal and topographic gradients. Journal of Vegetation Science 25: 160-171. DOI: https:// doi.org/10.1111/jvs. 12060
Kessler M. 2000. Elevational gradients in species richness and endemism of selected plant groups in the central Bolivian Andes. Plant Ecology 149: 181-193. DOI: https://doi.org/10.1023/A:1026500710274

Kessler M, Kluge J, Hemp A, Ohlemüller R. 2011. A global comparative analysis of elevational species richness patterns of ferns. Global Ecology and Biogeography 20: 868-880. DOI: https://doi.org/10.1111/j.1466-8238.2011. 00653.x

Kluge J, Kessler M, Dunn RR. 2006. What drives elevational patterns of diversity? A test of geometric constraints, climate and species pool effects for pteridophytes on an elevational gradient in Costa Rica. Global Ecology and Biogeography 15: 358-371. DOI: https://doi.org/10.1111/j.1466-822X.2006.00223.x

Koehler K, Center A, Cavender-Bares J. 2012. Evidence for a freezing tolerance-growth rate trade-off in the live oaks (Quercus series Virentes) across the tropical-temperate divide. New Phytologist 193: 730-744. DOI: https:// doi.org/10.1111/j.1469-8137.2011.03992.x

Krömer T, Kessler M, Gradstein RS, Acebey A. 2005. Diversity patterns of vascular epiphytes along an elevational gradient in the Andes. Journal of Biogeography 32: 1799-1809. DOI: https://doi.org/ 10.1111/j.1365-2699.2005.01318.x

Legendre P, Legendre LF. 2012. Numerical Ecology. Vol. 24. Amsterdam, Netherlands: Elsevier Science. ISBN: 9780444538680

Lomolino M. 2001. Elevation gradients of species diversity: Historical and prospective views. Global Ecology and Biogeography 10: 3-13. DOI: https://doi.org/10.1046/ j.1466-822x.2001.00229.x

Manos PS, Doyle JJ, Nixon KC. 1999. Phylogeny, biogeography and processes of molecular differentiation in Quercus subgenus Quercus (Fagaceae). Molecular Phylogenetics and Evolution 12: 333-349. DOI: https:// doi.org/10.1006/mpev.1999.0614

Mazerolle MJ. 2019. AICcmodavg: Model Selection and Multimodel Inference based on (Q)AIC(c). R package v.2.2-2.

McCain CM, Grytnes JA. 2010. Elevational gradients in species richness. In: Encyclopedia of Life Sciences. 1-10. DOI: https://doi.org/10.1002/9780470015902.a0022548

Middleton N, Thomas DSG. 1997. World Atlas of Desertification (United Nations Environment Programme). 2nd edition. Edward Arnold. London. ISBN: 0-340-69166-2

Morales-Saldaña S. 2017. Riqueza y distribución del género Quercus en la Sierra Madre del Sur, México. MSc. Thesis, Universidad Nacional Autónoma de México.

Morrone JJ. 2014. Biogeographical regionalisation of the Neotropical region. Zootaxa 3782: 1-110. DOI: http:// dx.doi.org/10.11646/zootaxa.3782.1.1 
Murphy J, Riley JP. 1962. A modified single solution method for the determination of phosphate in natural waters. Analytica Chimica Acta 27: 31-36. https:// doi.org/10.1016/S0003-2670(00)88444-5

Myers N, Mittermeier RA, Mittermeier CG, Fonseca GAB, Kent J. 2000. Biodiversity hotspots for conservation priorities. Nature 403: 853-858. DOI: https://doi.org/ $10.1038 / 35002501$

Negi SS, Naithani HB. 1995. Oaks of India, Nepal and Bhutan. International Distribution, Dehradun. India. ISBN: 8170892333

Nixon K. 1993. Infrageneric classification of Quercus (Fagaceae) and typification of sectional names. Annales des Sciences Forestières 50: 25-34. DOI: https://doi.org/ 10.1051/forest:19930701

Nixon K. 2006. Global Neotropical distribution and diversity of oaks (genus Quercus) and oak forests. In: Kappelle M, ed. Ecology and Conservation of Neotropical Montane Oak Forests, Ecological Studies185. Berlin: Springer. pp. 3-13. ISBN: 978-3-540-28909-8

Nogués-Bravo D, Araújo MB, Romdal T, Rahbek C. 2008. Scale effects and human impact on the elevational species richness gradients. Nature 453: 216-219. DOI: https://doi.org/10.1038/nature06812

Oksanen J, Blanchet FG, Friendly M, Kindt R, Legendre P, Mcglinn D, Minchin PB, O'Hara R, Simpson G, Solymos P. 2016. vegan: Community Ecology Package. Ordination Methods, Diversity Analysis and other Functions for Community and Vegetation Ecologists. v.2.4-0. https://CRAN.R-project.org/package=vegan

Pausas JG, Austin MP. 2001. Patterns of plant species richness in relation to different environments: An appraisal. Journal of Vegetation Science 12: 153-166. DOI: https://doi.org/10.2307/3236601

Pärtel M. 2002. Local plant diversity patterns and evolutionary history. Ecology 83: 2361-2366. DOI: https://doi.org/10.1890/0012-9658(2002)083[2361:LPDP AE]2.0.CO;2

Pickering CM, Green K. 2009. Vascular plant distribution in relation to topography, soils and micro-climate at five GLORIA sites in the Snowy Mountains, Australia. Australian Journal of Botany 57: 189. DOI: https:// doi.org/10.1071/BT08133

R Core Team 2017. R: A language and environment for statistical computing. Vienna, Austria: R Foundation for Statistical Computing. https://www.R-project.org/.

Rao M, Steinbauer MJ, Xiang X, Zhang M, Mi X, Zhang J, Ma K, Svenning JC. 2018. Environmental and evolutionary drivers of diversity patterns in the tea family (Theaceae s.s.) across China. Ecology and Evolution 8: 11663-11676. DOI: https://doi.org/10.1002/ $\underline{\text { ece } 3.4619}$
Robertson PG, Coleman DC, Bledsoe CS, Sollins P. 1999. Standard Soil Methods for Long-Term Ecological Research (LTER). New York: Oxford University Press. ISBN10: 019-512083-3; ISBN 13: 978-0195120837

Ramírez-Toro W, Torres-Miranda A, González-Rodríguez A, Ruiz-Sánchez E, Luna-Vega I, Oyama K. 2017. A multicriteria analysis for prioritazing areas for conservation of oaks (Fagaceae: Quercus) in Oaxaca, southern Mexico. Tropical Conservation Science 10: 1-29. DOI: https://doi.org/10.1177/1940082917714227

Rodríguez-Correa H, Oyama K, MacGregor-Fors I, González-Rodríguez A. 2015. How are oaks distributed in the Neotropics? A perspective from species turnover, areas of endemism, and climatic niches. International Journal of Plant Sciences 176: 222-231. DOI: https:// doi.org/10.1086/679904

Rosete-Vergés FA, Pérez-Damián JL, Villalobos-Delgado M, Navarro-Salas EN, Salinas-Chávez E, Remond-Noa R. 2014. El avance de la deforestación en México 1976-2007. Madera y Bosques 20: 21-35. ISSN 2448-7597

Rzedowski J. 2006. Vegetación de México. 1ra. Edición digital. México, DF: Comisión Nacional para el Conocimiento y Uso de la Biodiversidad.

Sánchez-González A, López-Mata L. 2005. Plant species richness and diversity along an altitudinal gradient in the Sierra Nevada, Mexico. Diversity and Distributions 11: 567-575. DOI: https://doi.org/10.1111/j.1366-9516.2005. $\underline{00186 . x}$

Salamon-Albert É, Abaligeti G, Ortmann-Ajkai A. 2017. Functional response trait analysis improves climate sensitivity estimation in beech forests at a trailing edge. Forests 8: 324. DOI: https://doi.org/10.3390/f8090324

Salas-Morales SH, Meave J. 2012. Elevational patterns in the vascular flora of a highly diverse region in southern Mexico. Plant Ecology 213: 1209-1220. DOI: https:// doi.org/10.1007/s11258-012-0077-6

Salas-Morales SH, Meave JA, Trejo I. 2015. The relationship of meteorological patterns with changes in floristic richness along a large elevational gradient in a seasonally dry region of southern Mexico. International Journal of Biometeorology 59: 1861-1874. DOI: https:// doi.org/10.1007/s00484-015-0993

SMN [Servicio Meteorológico Nacional] 2017. Normales Climatológicas por Estado https://smn.conagua.gob. $\underline{\mathrm{mx} / \mathrm{es} / \text { informacion-climatologica-por-estado?estado }=\mathrm{jal}}$ (accessed December 5, 2017).

Scherrer D, Körner C. 2011. Topographically controlled thermal-habitat differentiation buffers alpine plant diversity against climate warming. Journal of Biogeography 38: 406-416. DOI: https://doi.org/10.1111/ j.1365-2699.2010.02407.x 
Shen ZH, Fang JY, Chiu CA, Chen TY. 2015. The geographical distribution and differentiation of Chinese beech forests and the association with Quercus. Applied Vegetation Science 18: 23-33. DOI: https://doi.org/ $\underline{10.1111 / \text { avsc. } 12108}$

Styles BT. 1993. Genus Pinus: a Mexican preview. In: Ramammoorthy TP, Bye R, Lot A, Fa J, eds. Biological Diversity of Mexico. Nueva York: Oxford University Press, pp. 397-420. ISBN-13: 978-0195066746

Tang Z, Fang J. 2006. Temperature variation along the northern and southern slopes of Mt. Taibai, China. Agricultural and Forest Meteorology 139: 200-207. DOI: https://doi.org/10.1016/j.agrformet.2006.07.001

Torres-Miranda A, Luna-Vega I, Oyama K. 2011. Conservation biogeography of red oaks (Quercus, Section Lobatae) in Mexico and Central America. American Journal of Botany 98: 290-305. DOI: https:// doi.org/10.3732/ajb.1000218

Torres-Miranda A, Luna-Vega I, Oyama K. 2013. New approaches to the biogeography and areas of endemism of red oaks (Quercus L., Section Lobatae). Systematic Biology 62: 555-573. DOI: https://doi.org/10.1093/ sysbio/syt021

Tuomisto H, Zuquim G, Cárdenas G. 2014. Species richness and diversity along edaphic and climatic gradients in Amazonia. Ecography 37: 1034-1046. DOI: https://doi.org/10.1111/ecog.00770

Valencia-Á. S. 2004. Diversidad del género Quercus (Fagaceae) en México. Boletín de la Sociedad Botánica de México 75: 33-53. DOI: https://doi.org/10.17129/ botsci.1692

Vargas-Rodríguez YL, Platt WJ, Vázquez-García JA, Boquin G. 2010. Selecting relict montane cloud forests for conservation priorities: The case of western Mexico. Natural Areas Journal 30: 156-173. DOI: https://doi.org/ 10.3375/043.030.0204

Vargas-Rodríguez YL, Platt WJ, Urbatsch LE, Foltz DW. 2015. Large scale patterns of genetic variation and differentiation in sugar maple from tropical Central America to temperate North America. $B M C$ Evolutionary Biology 15:257. DOI: https://doi.org/ $\underline{10.1186 / \mathrm{s} 12862-015-0518-7}$

\footnotetext{
Associate editor: Enrique Jurado

Author Contributions: MAN., FGO. and KO. conceived and designed the research; MAN. and ATM. conducted field work; FGO. supervised the soil analysis; MAN., FGO., ATM. and OTV. contributed to data analyses. KO obtained the financial support for the research. MAN. and FGO. wrote the first draft of the paper and $\mathrm{KO}$ edited the final version. All authors contributed to drafts and agreed with the final manuscript.
}

Vázquez-García JA, Givnish T. 1998. Altitudinal gradients in tropical forest composition, structure, and diversity in the Sierra de Manantlán. Journal of Ecology 86: 999-1020. DOI: https://doi.org/10.1046/j.1365-2745. 1998.00325.x

Velázquez-Ruiz A, Martínez LM, Carrillo-González FM. 2012. Caracterización climática para la región de Bahía de Banderas mediante el sistema de Köppen, modificado por García, y técnicas de sistemas de información geográfica. Investigaciones Geográficas 79: 7-19.

Walthert L, Meier SE. 2017. Tree species distribution in temperate forests is more influenced by soil than by climate. Ecology and Evolution 7: 9473-9484. DOI: https://doi.org/10.1002/ece3.3436

Webb CO, Ackerly DD, McPeek MA, Donoghue MJ. 2002. Phylogenies and community ecology. Annual Review of Ecology and Systematics 33: 475-505. DOI: https:// doi.org/10.1146/annurev.ecolsys.33.010802.150448

Xu X, Dimitrov D, Shrestha N, Rahbek C, Wang Z. 2019. A consistent species richness-climate relationship for oaks across the Northern Hemisphere. Global Ecology and Biogeography 28: 1051-1066. DOI: https://doi.org/ $\underline{10.1111 / \text { geb. } 12913}$

Zhang SB, Chen WY, Huang JL, Bi YF, Yang XF. 2015. Orchid species richness along elevational and environmental gradients in Yunnan, China. PLOS ONE 10: e0142621. DOI: https://doi.org/10.1371/journal.pone. $\underline{0142621}$

Zhou J, Lang X, Du B, Zhang H, Liu H, Zhang Y, Shang L. 2016. Litterfall and nutrient return in moist evergreen broad-leaved primary forest and mixed subtropical secondary deciduous broad-leaved forest in China. European Journal of Forest Research 135: 77-86. DOI: https://doi.org/10.1007/s10342-015-0918-7

Zobel M. 2016. The species pool concept as a framework for studying patterns of plant diversity. Journal of Vegetation Science 27: 8-18. DOI: https://doi.org/ $\underline{10.1111 / j v s .12333}$

Zuur A, Ieno E, Walker N, Saveliev A, Smith G. 2009. Mixed Effects Models and Extensions in Ecology with R. New York: Springer Science \& Business Media. ISBN: 978-0-387-87457-9; DOI: https://doi.org/10.1007/978$\underline{0-387-87458-6}$ 


\section{Appendix 1. Potential evapotranspiration and aridity index calculations}

Potential evapotranspiration was calculated with Hargreaves and Samani (1985)'s method, based on the following equation:

$E T o=$ potential evapotranspiration by $\mathrm{mm} /$ day

$$
\text { Evap eq }=R s^{*} 1 / \lambda
$$

$\mathrm{C}_{i}=$ constant 0.0023

$\mathrm{T}_{\text {med }}=$ average temperature in ${ }^{\circ} \mathrm{C}$

$\mathrm{T}_{\max }=$ maximum temperature in ${ }^{\circ} \mathrm{C}$

$\mathrm{T}_{\text {min }}=$ minimum temperature in ${ }^{\circ} \mathrm{C}$

Evap eq= equivalent evaporation in $\mathrm{mm} /$ day

$\mathrm{R} s=$ Solar extraterrestrial radiation based on latitude and longitude in M Jules $/ \mathrm{m}^{2} /$ day (NASA 2016).

$1 / \lambda=$ inverse of the latent heat of vaporization (0.408) (Allen et al. 2006).

The aridity index proposed by the United Nations for the Environment (UNEP) expresses the relationship between average annual precipitation $(\mathrm{Pa})$ and potential evapotranspiration (Evpot) in a given area (Middleton \& Thomas 1997), which was calculated as: $\mathrm{I}=$ Pa/Evpot.

\section{Literature cited}

Allen RG, Pereira LS, Raes D, Smith M. 2006. Evapotranspiración del cultivo: guías para la determinación de los requerimientos de agua de los cultivos. Food \& Agriculture Organization. Rome, Italy. ISBN: 92-5-304219-2

Middleton N, Thomas DSG. 1997. World Atlas of Desertification (United Nations Environment Programme). 2nd edition. Edward Arnold. London. ISBN: 0-340-69166-2

NASA [National Aeronautics and Space Administration] 2017. Solar extraterrestrial radiation Solar extraterrestrial radiation https://power.larc.nasa.gov/data-access-viewer/ (accessed November 25, 2016).

Hargreaves GH, Samani ZA. 1985. Reference crop evapotranspiration from temperature. Applied Engineering in Agriculture 1: 96-99. DOI: http://dx.doi.org/10.13031/2013.26773. 


\section{Appendix 2. Estimates of the coefficients of the best models of generalized linear models (GLM).}

\section{Climatic variables}

Mtcm, Minimum temperature of the coldest month; Pwq, Precipitation of the wettest quarter of the year; Tar, Temperature annual range; Pcq, Precipitation of the coldest quarter; UNEP, aridity index.

\begin{tabular}{|c|c|c|c|c|c|c|}
\hline Richness & & Estimate & Std. Error & $Z$ value & $\operatorname{Pr}(>|z|)$ & AICc \\
\hline \multirow[t]{3}{*}{ All } & Intercept & 5.514 & 7.049 & 0.782 & 0.043 & 173 \\
\hline & Pwq & -0.124 & 0.450 & -0.277 & 0.041 & \\
\hline & UNEP & -0.494 & 1.034 & -0.478 & 0.014 & \\
\hline \multirow[t]{2}{*}{ Pinus } & Intercept & 2.398 & 0.914 & 2.624 & 0.008 & 97.89 \\
\hline & Mtcm & -0.060 & 0.033 & -1.776 & 0.043 & \\
\hline \multirow[t]{4}{*}{ Quercus } & Intercept & 5.581 & 38.791 & 0.144 & 0.886 & 112.3 \\
\hline & Pcq & 0.057 & 2.937 & 0.02 & 0.978 & \\
\hline & Pwq & -0.701 & 4.013 & -0.175 & 0.899 & \\
\hline & UNEP & 0.123 & 4.897 & 0.025 & 0.978 & \\
\hline \multirow[t]{4}{*}{ Lobatae } & Intercept & -2.974 & 49.392 & -0.06 & 0.085 & 91.06 \\
\hline & Pwq & -0.048 & 5.088 & -1.723 & 0.013 & \\
\hline & Pcq & 0.957 & 3.766 & 0.254 & 0.566 & \\
\hline & UNEP & -1.308 & 6.300 & -0.208 & 0.103 & \\
\hline \multirow[t]{4}{*}{ Quercus s.s. } & Intercept & -12.934 & 41.165 & -0.314 & 0.753 & 66.71 \\
\hline & Mtcm & 1.223 & 3.038 & 0.403 & 0.786 & \\
\hline & Tar & 1.662 & 6.179 & 0.269 & 0.82 & \\
\hline & Pcq & -0.090 & 1.1280 & -0.08 & 0.982 & \\
\hline
\end{tabular}

\section{Relief variables}

Elev, Elevation; Slp, slope steepness; Asp, aspect.

\begin{tabular}{|c|c|c|c|c|c|c|}
\hline Richness & & Estimate & Std. Error & $Z$ value & $\operatorname{Pr}(>|z|)$ & AICc \\
\hline \multirow[t]{4}{*}{ All species } & Intercept & 2.267 & 0.23 & 9.857 & $2 \mathrm{e}-16$ & 175.85 \\
\hline & Elev & $-9.37 \mathrm{e}-05$ & $1.16 \mathrm{e}-04$ & -0.803 & 0.442 & \\
\hline & Asp & $5.09 \mathrm{e}-04$ & $5.39 \mathrm{e}-04$ & 0.943 & 0.232 & \\
\hline & Slo & $-4.77 \mathrm{e}-08$ & $4.10 \mathrm{e}-08$ & -1.163 & 0.254 & \\
\hline \multirow[t]{2}{*}{ Pinus } & Intercept & -4.704 & 2.820 & -1.668 & 0.095 & 98.47 \\
\hline & Elev & 0.736 & 0.377 & 1.952 & 0.040 & \\
\hline \multirow[t]{4}{*}{ Quercus } & Intercept & 1.676 & 3.305 & 0.507 & 0.061 & 112.76 \\
\hline & Elev & -0.050 & 0.305 & -0.165 & 0.679 & \\
\hline & Asp & 0.114 & 0.095 & 1.200 & 0.297 & \\
\hline & Slope & -0.057 & 0.185 & -0.308 & 0.448 & \\
\hline \multirow[t]{2}{*}{ Lobatae } & Intercept & 0.293 & 0.901 & 1.326 & 0.074 & 88.31 \\
\hline & aspect & 0.074 & 0.172 & 1.430 & 0.034 & \\
\hline \multirow[t]{3}{*}{ Quercus s.s. } & Intercept & 1.295 & 4.065 & 0.319 & 0.750 & 63.97 \\
\hline & aspect & 0.034 & 0.123 & 0.282 & 0.911 & \\
\hline & slope & -0.076 & 0.280 & -0.274 & 0.843 & \\
\hline
\end{tabular}


Arenas-Navarro et al. / Botanical Sciences 98(2): 219-237. 2020

\section{Soil variables}

TC, Total Carbon; TN, Total Nitrogen; TP, Total Phosphorus; $\mathrm{NO}_{3}$; N Nitrate; pHs, soil pH and Sm, soil moisture.

\begin{tabular}{|c|c|c|c|c|c|c|}
\hline Richness & & Estimate & Std. Error & $Z$ value & $\operatorname{Pr}(>|z|)$ & AICc \\
\hline \multirow[t]{3}{*}{ All species } & Intercept & 5.9612 & 1.2768 & 4.669 & $3.03 \mathrm{e}-06$ & 165.08 \\
\hline & $\mathrm{pHs}$ & -1.7930 & 0.7099 & -2.526 & 0.0115 & \\
\hline & $\mathrm{Sm}$ & -0.2567 & 0.1191 & -2.155 & 0.0302 & \\
\hline \multirow[t]{3}{*}{ Pinus } & Intercept & 1.95394 & 0.64651 & 3.022 & 0.00251 & 100.86 \\
\hline & $\mathrm{TC}$ & 0.31876 & 0.18017 & 1.769 & 0.08786 & \\
\hline & NO3- & -0.05410 & 0.03758 & -1.440 & 0.08497 & \\
\hline \multirow[t]{4}{*}{ Quercus } & Intercept & 3.59608 & 1.3537 & 2.656 & 0.0079 & 112.24 \\
\hline & $\mathrm{TC}$ & 2.35352 & 4.83049 & 0.487 & 0.4611 & \\
\hline & $\mathrm{pHs}$ & -0.3875 & 0.2454 & -1.579 & 0.3734 & \\
\hline & $\mathrm{Sm}$ & -0.01878 & 0.01055 & -1.780 & 0.0160 & \\
\hline \multirow[t]{3}{*}{ Lobatae } & Intercept & 2.0486 & 1.6561 & 1.237 & 0.216 & 90.96 \\
\hline & $\mathrm{TC}$ & 2.3309 & 5.5546 & 0.420 & 0.401 & \\
\hline & $\mathrm{pHs}$ & -0.2635 & 0.3161 & -0.834 & 0.509 & \\
\hline \multirow[t]{2}{*}{ Quercus s.s. } & Intercept & 0.5524 & 0.2636 & 2.096 & 0.0361 & 61.4 \\
\hline & $\mathrm{TN}$ & -307.5232 & 186.9178 & -1.645 & 0.0999 & \\
\hline
\end{tabular}

